\title{
Root morphology and mycotrophy of Disperis neilgherrensis (Orchidaceae) from Western Ghats, southern India
}

\author{
Thangavelu Muthukumar ${ }^{1}$, Eswaranpillai Uma ${ }^{1}$ \& Radha Raman Pandey ${ }^{2}$ \\ 1 Root and Soil Biology Laboratory, Department of Botany, Bharathiar University, Coimbatore 641 046, Tamil Nadu, India. \\ 2 Department of Life Sciences, Manipur University, Canchipur, Imphal 795 003, India.
}

\section{Correspondence}

T. Muthukumar

E-mail: tmkum@yahoo.com

Received: 15 October 2013

Accepted: 23 October 2013

Published on-line: 13 November 2013

\section{Resumen}

Morfología radicular y microtrofia de Disperis neilgherrensis (Orchidaceae) de los Ghats occidentales, India meridional

Por primera vez se examinó la morfología radicular y la microtrofia de Disperis neilgherrensis Wight., provenientes de los Ghats occidentales, India meridional. El sistema radicula es disperso, consistiendo en una raices blancas delgadas de $0,28 \pm 0,11 \mathrm{~mm}$, que parten de un rizoma marrón. Las raíces están cubiertas por pelos radiculares $(19,2 \pm 1,5$ por $\mathrm{mm}$ de raíz) de 161,80 $\pm 12,68 \mu \mathrm{m}$ de largo y $4,55 \pm 1,17 \mu \mathrm{m}$ de ancho. Las celulas corticales contenían estructuras fúngicas típicas de micorrizas orquidoides (OM) y arbusculares (AM). En contraste, los rizomas sólo presentan estructuras OM. La colonización OM se caracteriza por presentar ovillos manchados claros u obscuros, con hifas regularmente septadas de diámetros variados. La colonización AM se caracteriza por ovillos hifales intracelulares no septados, arbúsculos y vesículas intracelulares. El porcentaje de longitud con colonización OM fue de 56,51\% para raíces y $73,64 \%$ para rizomas, mientras que la longitud de raíz con colonización AM fue de $30,23 \%$. En tipo de AM en $D$. neilgherrensis corresponde al tipo Paris.

Palabras clave: Arbuscular, Morfología radicular, Micorriza, Pelotones.

\begin{abstract}
We examined the root morphology and mycotrophy of Disperis neilgherrensis Wight., growing in the Western Ghats of south India for the first time. The root system was sparse consisting of white to off white, $0.28 \pm 0.11 \mathrm{~mm}$ thick roots arising from short brown rhizome. The roots were covered by root hairs $(19.2 \pm 1.5$ per $\mathrm{mm}$ of root) $161.80 \pm 12.68 \mu \mathrm{m}$ long and $4.55 \pm 1.17 \mu \mathrm{m}$ thick. Root cortical cells contained fungal structures typical for orchid mycorrhizal (OM) and arbuscular mycorrhizal (AM) types. In contrast, rhizomes contained only $\mathrm{OM}$ fungal structures. The $\mathrm{OM}$ colonization was characterized by both lightly and darkly staining pelotons with regularly septate hyphae of varied diameters. Intracellular aseptate hyphal coils, arbusculate coils and intracellular vesicles characterized AM colonization. The percentage of length with OM colonization was $56.51 \%$ for roots and $73.64 \%$ for rhizomes, whereas the root length with AM fungal colonization was $30.23 \%$. The AM type in $D$. neilgherrensis corresponds to the Paris-type.
\end{abstract}

Key words: Arbuscular, Root morphology, Mycorrhiza, Pelotons. 


\section{Introduction}

Orchidaceae with around 26500 species and varied life-history strategies are well known for their dependence on specific mycorrhizal and pollinator symbioses (Smith \& Read 2008, Royal Botanic Garden, Kew 2011, Waterman et al. 2011). Invariably, all orchids investigated so far require mycorrhizal association for seed germination and seedling development under natural conditions (Rasmussen \& Rasmussen 2009). Nevertheless, the extent of the dependence on mycorrhizal fungi for carbon and nutrient uptake tend to vary with orchids through adulthood with the dependence on the fungus being complete for mycoheterotrophic forms (Smith \& Read 2008). In spite of their large numbers, only a small percentage $(0.31 \%)$ of orchids has been examined for their mycorrhizal status (Wang \& Qiu 2006). Generally, orchids associate with the polyphyletic Rhizoctonia DC., where the fungus forms elaborate coiled structures known as pelotons within cortical cells (Dearnaley 2007). In addition, orchids could also associate with a wide range of endophytic fungi, including those forming ectomycorrhizal and arbuscular mycorrhizal (AM) associations (Wang \& Qiu 2006, Muthukumar et al. 2011).

In addition to the anchorage of the plant to the substrate, roots play an important role in the acquisition of nutrients from the substrates. The efficiency of nutrient uptake is largely influenced by the morphology of the roots which vary greatly with plant species and environmental conditions (Hodge et al. 2009). A few previous investigations on root morphology of orchids especially terrestrial forms do indicate the existence of wide variations in root morphology of terrestrial orchids (Muthukumar \& Sathiyadash 2009, Muthukumar et al. 2011, Sathiyadash et al. 2012).

Swartz (1800) erected the genus Disperis to encompass a number of terrestrial orchids with peculiar flower characters from Western Cape of South Africa. Flowers of Disperis are characterized by spurred lateral sepals and a reflexed lip bearing complex appendage (Kurzweil \& Manning 2005). This African genus with 74 species is placed under the subfamily Orchidoideae, tribe Diseae and subtribe Coryciinae. This genus though is well represented in humid African tro- pics and Madagascar, a single highly variable and widespread species $D$. neilgherrensis Wight., occurs in tropical Asia (Kurzweil 2005, Kurzweil \& Manning 2005). D. neilgherrensis has been reported to be very rare in the Western Ghats (Abraham \& Vatsala 1981). In addition, few taxa in Disperis spp., such as D. kamerunensis Schltr., D. nitida Summerh. and D. mildbraedii Schltr. ex Summerh. are listed under threatened taxa. The mycorrhizal status of Disperis spp. has not been investigated previously. Therefore, we investigated the root morphology and mycotrophy of $D$. neilgherrensis occurring in Western Ghats of southern India.

\section{Materials and methods}

In May 2011, we collected five plants of D. neilgherrensis in flowering stage from woodlands of Top Slip, Indira Gandhi Wildlife Sanctuary and National Park of Tamil Nadu, India (76 $49^{\prime}$ $77^{\circ} 21^{\prime} \mathrm{E}, 10^{\circ} 13^{\prime}-10^{\circ} 33^{\prime} \mathrm{N}$ ), at an elevation of 300 masl. The annual rainfall ranges between 500 and $5000 \mathrm{~mm}$. The plants grew in the superficial, highly organic rich layer of the forest floor under shady conditions.

Three plants (two in vegetative and one in flowering stage) were carefully removed, and the rhizomes and roots of each plant were washed free of adhering substrates after photographing. Rhizomes and roots were then immediately fixed in FAA [ethanol (70\%) - formalin (37\%) - acetic acid at 9:0.5:0.5] and stored. The substrate adjacent to the plants was collected for the examination of the presence of AM fungal spores. The presence of AM fungal spores in the substrate samples were examined by modified wet-sieving and decanting technique (Muthukumar et al. 1996).

Root and rhizome thickness, root hair number, and root hair length and width were measured on five $1-\mathrm{cm}$ long root or rhizome bits using micrometry. Clearing and staining of roots and rhizomes for mycorrhizal assessment were performed as in Koske and Gemma (1989). A bright field Olympus BX51 microscope attached with Progres 2 camera was used to quantify the colonization at $x$ 400 magnifications and photograph the mycorrhizal morphology. The extent of root length colonized by different fungal structures was deter- 
mined according to McGonigle et al. (1990).

Colonization pattern was designated as orchid mycorrhizal $(\mathrm{OM})$ when the colonizing fungal hyphae were regularly septate and forming pelotons. In contrast, the colonization was considered as $\mathrm{AM}$ if the colonizing linear hyphae or hyphal coils were aseptate and with arbuscules and/or vesicles. Data are presented as mean \pm standard error.

\section{Results}

Roots were sparse, arising from a short rhizome, white to off white, $0.28 \pm 0.11 \mathrm{~mm}$ thick with adhering organic matter (Fig. 1a). Average root hair numbers were $19.2 \pm 1.5$ per mm of root, 161.80 $\pm 12.68 \mu \mathrm{m}$ long and $4.55 \pm 1.17 \mu \mathrm{m}$ in diameter. Rhizomes were short, cylindrical, brown, 1.75 $\pm 0.92 \mathrm{~mm}$ long and $3.61 \pm 1.41 \mathrm{~mm}$ in thickness.

Fungal colonization of roots was characterized by the presence of both OM and AM fungal structures, whereas, rhizomes contained only OM fungal structures. Cortical cells containing OM fungal structures lacked AM fungal structures and vice versa. Fungal penetration of the roots by AM fungi occurred from ramifications of the hyphae originating from the runner hyphae often preceded by the formation of an appressorium on the root surface. In contrast, OM fungal entry of roots was through root hairs (Fig. 1b).

The pelotons of OM fungi were found uniformly distributed throughout the cortex. The size of the intact pelotons were $113.33 \pm 6.15 \times 89.72$ $\pm 4.83 \mu \mathrm{m}$ in roots and $135.12 \pm 7.86 \times 98.42 \pm$ $6.38 \mu \mathrm{m}$ in rhizomes. The OM fungal hyphae in roots were slightly thicker $(4.67 \pm 0.67 \mu \mathrm{m})$ compared to those of roots $(3.15 \pm 0.58 \mu \mathrm{m})$. We did not observe any clamp connections on OM fungal hyphae or fungal moniliod cells in any of the root or rhizome samples examined. The percentage of root or rhizome length with intact pelotons was $42.99 \pm 5.12 \%$ for roots and $58.52 \pm 6.73 \%$ for rhizomes. The percentage of root length with degenerating pelotons was low in both roots (13.52 $\pm 1.91 \%)$ and rhizomes $(15.12 \pm 1.36 \%)$.

Two types of intact pelotons based on staining and hyphal diameter could be distinguished in the roots. In the first type, the fungal hyphae was darkly stained and thicker in diameter $(3.15 \pm$ $0.58 \mu \mathrm{m})$, while in the second type, the fungal hy- phae were slightly thinner $(2.31 \pm 0.12 \mu \mathrm{m})$ and lightly stained (Fig. 1c, d).

The AM colonization pattern resembles typical Paris-type with intracellular hyphal coils, arbusculate coils (Fig. 1e), and intracellular vesicles. The aseptate AM fungal hyphae was $5.82 \pm 0.36$ $\mu \mathrm{m}$ in diameter forming hyphal coils in the cortical cells (Fig. 1f). Arbuscules are formed on these hyphal coils with their thin branches in older parts of the roots degenerating to amorphous clumps. Vesicles were oval, terminal, thick walled measuring $70.52 \pm 6.61 \times 41.28 \pm 4.21 \mu \mathrm{m}$ and occurred intracellularly (Fig. 1g). The percentage of root length with AM colonization was $30.23 \pm 5.31 \%$. Similarly, the percentage of root length with AM fungal hyphal coils, arbusculate coils and vesicles was $12.60 \pm 1.84 \%, 16.32 \pm 2.74 \%$ and $1.28 \pm$ $0.24 \%$ respectively.

Both OM and AM fungal colonization was restricted to the cortical region with the endodermis and stele were free from fungal structures. Similarly, the root tip cells were devoid of fungal structures. We could not retrieve any intact or identifiable AM fungal spores from any of the substrate samples.

\section{Discussion}

Most of the earlier records do indicate the distribution of D. neilgherrensis between 600 and 2000 masl (Kurzweil 2005). However, the plants examined in the present study occurred at an elevation of 300 masl, which resembles the distribution in Philippines and Taiwan where the plants grow between 250 and 750 masl (Kurzweil 2005).

Roots of $D$. neilgherrensis are thinner compared to roots of other terrestrial orchids investigated so far. Nevertheless, the root hair number per $\mathrm{mm}$ of the root is similar to those of Zeuxine gracilis (Breda) Blume and is well within the range of 6-35 per mm of root as reported for other terrestrial orchids (Muthukumar et al. 2011, Sathiyadash et al. 2012). Similarly, the root hair length and diameter of $D$. neilgherrensis resembles those of Habenaria roxburghii Nicolson and Z. gracilis respectively (Muthukumar et al. 2011, Sathiyadash et al. 2012).

The mycorrhizal status of Disperis spp., is unknown prior to this study. Orchid mycorrhizae formed by members of Ascomycota and Basi- 


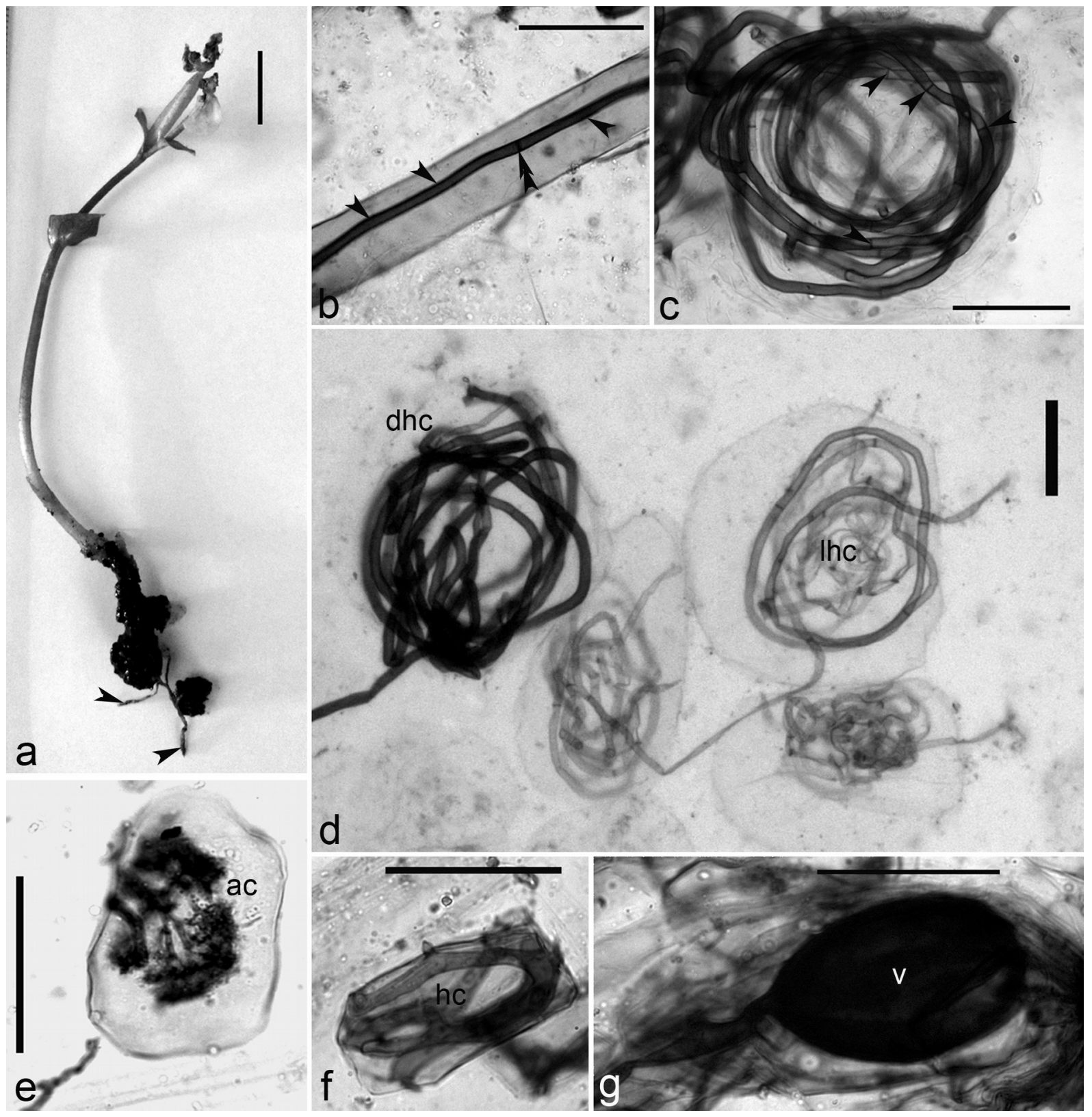

Figura 1. Hábito y mofología de la micorriza de Disperis neilgherrensis. a: Hábito con raíces (flechas) unidas a materia orgánica. b: Hifas (flechas) con septos (flecha doble) dentro de pelo radicular. c: Ovillos de hifas oscuras con septos (flechas). d: Células del córtex radicular con ovillos de hifas oscuros (dhc) y claros (lhc). e: Ovillo arbuscular (ac) de hongo AM con célula cortical. f: Ovillo hifal grueso aseptado (hc) de hongo AM. g: Vesícula (v) intracelular de hongo AM. Líneas de escala: a= $5 \mathrm{~cm} ; \mathrm{b}-\mathrm{g}=50 \mu \mathrm{m}$.

Figure 1. Habit and mycorrhizal morphology of Disperis neilgherrensis. a: Habit with roots (arrow heads) attached to organic matter. b: Fungal hyphae (arrow heads) with septation (double arrow head) within root hair. c: Darkly staining hyphal coil with septations (arrow heads). d: Root cortical cells with darkly (dhc) and lightly (lhc) staining hyphal coils. e: Arbusculate coil (ac) of AM fungi within a cortical cell. f: Broad aseptate hyphal coil (hc) of AM fungi. g: Intracellular AM fungal vesicle (v). Scale bars: a= $5 \mathrm{~cm} ; \mathrm{b}-\mathrm{g}=50 \mu \mathrm{m}$.

diomycota are commonly reported for the terrestrial orchids (Elena et al. 2010). In this study, field collected roots of $D$. neilgherrensis contained AM fungal structures. A few previous studies have noted the presence of AM fungal association in orchids. Roots of Anoectochilus elatus Lindl., Calanthe masuca (D. Don) Lindl., Chrysoglossum maculatum (Thwaites) Hook. f., Habenaria elliptica Wight and Malaxis rheedei Blume inves- tigated from the tropical forests of Western Ghats contained AM fungal structures (Raman \& Nagarajan 1999). Similarly, AM fungal structures have also been reported in roots of Corybas macranthus (Hook. f.) Rchb. f. and Z. gracilis (Hall 1976, Muthukumar et al. 2011). Nevertheless, unlike D. neilgherrensis, AM fungal association reported in terrestrial orchids so far is atypical characterized by the presence of only hyphae 
and vesicles. However, Raman \& Nagarajan (1999) also reported the presence of arbuscules in mycorrhizal roots of $A$. elatus and $H$. elliptica growing in the Kodaikanal forests of the Western Ghats in southern India.

The entry of OM fungi into roots was through the root hairs as observed for terrestrial orchids like Cephalanthera longifolia (L.) Fritsch, Dactylorhiza majalis (Rchb.) P.F. Hunt \& Summerh. (Làtr et al. 2008), Phaius tankervillieae (Banks ex L'Herit) Blume (Muthukumar \& Sathiyadash 2009), Spathoglottis plicata Blume (Senthilkumar et al. 2001), Z. gracilis (Muthukumar et al. 2011) and species belonging to Calanthe R. Brown, Eulophia R. Brown \& Lindl., Habenaria Willd., Malaxis Sw., and Satyrium Sw. (Sathiyadash et al. 2012). In contrast, AM fungi entered the roots through the epidermis after forming and appressorium at the point of entry (Smith \& Read 2008).

The extent of OM colonization in D. neilgherrensis is similar to those reported for P. tankervillieae, and higher than those reported for Calanthe triplicata (Willem.) Ames (44\%) and Eulophia epidendraea (J. König ex Retz.) C. E. C. Fisch. $(42.27 \%)$, but less than other terrestrial orchids where the extent of colonization is $>60 \%$ of the root length (Muthukumar \& Sathiyadash 2009; Muthukumar et al. 2011, Sathiyadash et al. 2012). The presence of OM fungal structures in the rhizome of $D$. neilgherrensis is line with the previous observations for Chamaegastrodia shikokiana Makino \& F. Maek. (Yagame et al. 2008), Z. gracilis (Muthukumar et al. 2011) and Zeuxine strateumatica (L.) Schltr. (Porter 1942) where the rhizomes were found to be colonized by OM fungi. But these observations contradict those in $C$. longifolia where the rhizomes lacked any OM fungal structures (Làtr et al. 2008). The different hyphal morphology and staining intensity of pelotons in the present study clearly indicates colonization of $D$. neilgherrensis roots by more than one $\mathrm{OM}$ fungus. Colonization of terrestrial orchids by different OM fungi has been well demonstrated by both culture dependent and independent approaches (Rasmussen 2002; Bonnardeaux et al. 2007). Of the two OM forms described by Burgreff (1932), D. neilgherrensis fits into the tolypophagy. In this mycorrhizal form termed as mycophagy by Rasmussen \& Rasmussen (2009), the nutrients are released through the digestion of the fungal coils. Tolypophagy appears to the domi- nant and universal phenomenon in orchid roots and rhizomes as indicated by Peterson \& Massicotte (2004). Recolonization of cells during peloton lysis may occur in orchid roots that are perennial (Rasmussen \& Whigham 2002). Nevertheless, no recolonization of the lysing cells was evident in the roots and rhizomes of D. neilgherrensis.

The AM of D. neilgherrensis corresponds to the Paris-type which has been suggested as the best mycorrhizal strategy for plants growing under high stress or low nutrient and light conditions (Dickson et al. 2007). As the slow colonization of roots in Paris-type draws less energy from the host plant while reciprocally providing the nutrient, this type of AM could be advantageous for $D$. neilgherrensis which grows in the shaded forest floor. Imhof (2009) also speculated that the Paristype could have evolved due to the high evolutionary pressure for plants growing in deeply shaded habitats to select an efficient mycorrhizal form. The role of Paris-type AM in plant nutrient acquisition has been adequately demonstrated for AM plants (Dickson et al. 2007); such type of plant benefit is yet to be shown for orchids. Further, to our knowledge, AM type has been reported for the first time in orchids. The root length with AM colonization in D. neilgherrensis is higher compared to those of $Z$. gracilis (Muthukumar et al. 2011). Though an intense mycorrhizal colonization of roots $(>60 \%)$ has been reported for terrestrial orchids growing in Kodaikanal Hills of the Western Ghats, south India by Raman \& Nagarajan (1999), no distinction has been made between $\mathrm{OM}$ and $\mathrm{AM}$ colonization types. Roots of D. neilgherrensis were colonized by AM fungi in spite of the absence of spores in the substrates. This is not surprising as propagules like the extraradical hyphae originating from the roots of AM plants or organic matter could have initiated colonization (Smith \& Read 2008, Posada et al. 2012). However, further studies are necessary to understand whether AM fungi benefits $D$. neilgherrensis through uptake and translocation of nutrients like phosphorus as in other AM hosts.

\section{References}

Abraham A \& Vatsala P. 1981. Introduction to orchids. Tropical Botanic Garden and Research Institute, Trivandrum, India. 
Bonnardeaux Y, Brundrett M, Batty A, Dixon K, Koch J \& Sivasithamparam K. 2007. Diversity of mycorrhizal fungi of terrestrial orchids: compatibility webs, brief encounters, lasting relationships and alien invasions. Mycological Research 111: 51-61.

Burgeff H. 1932. Saprophytismus und Symbiose. Studien an Tropischen Orchideen, Jena, Gustav Fischer.

Dearnaley JDW. 2007. Further advances in orchid mycorrhizal research. Mycorrhiza 17: 475-486.

Dickson S, Smith FA \& Smith SE. 2007. Structural differences in arbuscular mycorrhizal symbiosis. More than 100 years after Gallaud, where next? Mycorrhiza 17: 375-393.

Elena V, Gastaldo A, Tondello A, Baldan B, Villani M \& Squartini A. 2010. Identification of two fungal endophytes associated with the endangered orchid Orchis militaris L. Journal of Microbiology and Biotechnology 20: 630-636.

Hall IR. 1976. Vesicular arbuscular mycorrhizas in the orchid Corybas macranthus. Transactions of the British Mycological Society 66: 160.

Hodge A, Berta G, Doussan C, Merchan F \& Crespi M. 2009. Plant root growth, architecture and function. Plant and Soil 321: 153-187.

Imhof S. 2009. Arbuscular, ecto-related, orchid mycorrhizas-three independent structural lineages towards mycoheterotrophy: Implications for classification? Mycorrhiza 19: 357-363.

Koske RE \& Gemma JN. 1989. A modified procedure for staining roots to detect VA mycorrhizas. Mycological Research 92:486-488.

Kurzweil H. 2005: Taxonomic studies in the genus Disperis (Orchidaceae) in southeast Asia. Blumea 50, 143-152.

Kurzweil H \& Manning JC. 2005, A synopsis of the genus Disperis Sw. (Orchidaceae). Adansonia 27: 155-207.

Làtr A, Čuřikova M, Balàž M \& Uurčak J. 2008. Mycorrhizas of Cephalanthera longifolia and Dactylorhiza majalis, two terrestrial orchids. Annales Botanici Fennici 45: 281-289.

McGonigle TP, Miller MH, Evans DG, Fairchild GL, \& Swan JA. 1990. A method which gives an objective measure of colonization of roots by vesicular-arbuscular mycorrhizal fungi. New Phytologist 115: 495501.

Muthukumar T \& Sathiyadash K. 2009. Mycorrhizal morphology of Nun's orchid [Phaius tankervillieae (Banks ex L' Herit.) Blume]. Mycorrhiza News 21: 911.

Muthukumar T, Udaiyan K \& Manian S. 1996. Vesicular arbuscular mycorrhizae in tropical sedges of southern India. Biology and Fertility of Soils 22:96-100.

Muthukumar T, Uma E, Karthikeyan A, Sathiyadash K,
Jaison J, Priyadharsini P, Chongtham I \& Muniappan V. 2011. Morphology, anatomy and mycorrhizae in subterranean parts of Zeuxine gracilis (Orchidaceae). Anales de Biología 33: 127-134.

Peterson RL \& Massicotte H. 2004. Exploring structural definitions of mycorrhiza with emphasis on nutrient-exchange interfaces. Canadian Journal of Botany 82: 1074-1088.

Posada RH, Madriñan S \& Rivera EL. 2012. Relationships between the litter colonization by saprotrophic and arbuscular mycorrhizal fungi with depth in a tropical forest. Fungal Biology 116: 747-755.

Porter JN. 1942. The mycorrhiza of Zeuxine strateumatica. Mycologia 34: 380-390.

Raman N \& Nagarajan N. 1999. Mycorrhizal association of orchids in a tropical forest of southern India. Journal of Tropical Forest Science 11: 548-553.

Rasmussen HN. 2002. Recent developments in the study of orchid mycorrhiza. Plant and Soil 244:149163.

Rasmussen HN \& Rasmussen FN. 2009. Orchid mycorrhiza: implications of a mycophagous life style. Oikos 118: 334-345.

Rasmussen HN \& Whigham DF. 2002. Phenology of roots and mycorrhiza in five orchid species differing in phototropic strategy. New Phytologist 154: 797807.

Royal Botanical Garden, Kew. 2011. World checklist of selected plant families. http://apps.kew.org/ wcsp/incfamilies.do (accessed on 10 May 2012)

Sathiyadash K, Muthukumar T, Uma E \& Pandey RR. 2012. Mycorrhizal association and morphology in orchids. Journal of Plant Interactions 7: 238-247.

Senthilkumar S, Saravanakumar P, Krishnamurthy KV \& Britto J. 2001. Morphological and structural features of mycorrhizal roots of Spathoglottis plicata and Dendrobium species. Phyta 5: 1-6.

Smith SE \& Read DJ. 2008. Mycorrhizal symbiosis. 2nd ed. San Diego (CA), Academic press.

Swartz O. 1800. Orchidernes slagter och acter upstallde. Kongl. Vetenskaps Academiens Nya Handlingar 21: 202-254.

Wang B \& Qiu YL. 2006. Phylogenetic distribution and evolution of mycorrhizas in land plants. Mycorrhiza 16: 299-363.

Waterman RJ, Bidartondo MI, Stofberg J, Combs JK, Gebauer G, Savolainen V, Barraclough TG \& Pauw A. 2011. The effects of above- and belowground mutualism on orchid speciation and coexistence. American Naturalist 177: 54-68.

Yagame T, Yamato M, Suzuki A \& Iwase K. 2008. Ceratobasidiaceae mycorrhizal fungi isolated from nonphotosynthetic orchid Chamaegastrodia sikokiana. Mycorrhiza 18: 97-101. 